\title{
The Relationship Between the Tasks Aimed at the Prevention of Extraordinary Incidents, the Preparation for the Mitigation of their Consequences and the System of Protection ${ }^{1}$
}

\author{
Júlia HORNYACSEK ${ }^{2}$
}

\begin{abstract}
Extraordinary incidents, including disasters, usually cause significant damage to nature, the built environment and human lives. An approach, accepted by experts, is gaining more and more ground in the field of protection and research: it is not enough to respond to incidents following their occurrence, but great attention should be paid to prevent them, and authorities should be fully prepared to mitigate their consequences in due time. What does the preparation for extraordinary incidents mean, where is the place of these tasks in the system of protection, what are the tasks of the prevention phase, and how can the preparation activity be more efficient? In the article the author analyses the complex system of protection/defence, its subsystems, and then she demonstrates the place of disaster management and its subsystems in this environment. She examines the tasks of preventative protection against threat factors, with special regards to the tasks of the prevention/preparation phase. In the light of Hungarian and international prevention practice, she shows the up-to-date methods and tools with the help of several examples.
\end{abstract}

Keywords: complex system of protection, disaster management, hazards, prevention, preparation, protection, rehabilitation, flood, wild fires

\section{Introduction}

The pursuit of security, the protection of human life and essential material goods has been a part of community life ever since the beginning of humanity. The subject not only enjoys the priority of professionals, but also of scientists, so the various aspects of protection have been focused on by researchers, and also the possibilities of increasing the efficiency of implementation. A series of papers examines this special field dealing with the "natural study" of situations resulting from the emergence of extraordinary incidents, the types and features of damage, but also the implementation of the protection of the population and the establishment and operation of organizations responsible for the implementation as well. These writings approach the question differently depending on what purpose they were made for. In them, however, there is a perceptible similarity in that individual sectors draw their

The work was created in commission of the National University of Public Service under the priority project PACSDOP-2.1.2-CCHOP-15-2016-00001 titled "Public Service Development Establishing Good Governance” in the Miklós Zrínyi Habilitation Program.

2 Ph.D., associate professor, National University of Public Service, Faculty of Military Sciences and Officer Training; e-mail: hornyacsek.julia@uni-nke.hu; ORCID code: 8695713152-13391. 
conclusions and make their upgrading proposals mostly based on their own professional filters, their own terminology and profession-specific interpretation.

The various hazard factors - including natural and man-made disasters-are inherent in our times. According to UN data, between 2005 and 2015, more than 700,000 people were killed, the number of injured was over 1.4 million and about 23 million became homeless as a result of disasters. Over the past period, in overall, more than 1.5 billion people were affected by disasters. The total economic loss exceeded 1.3 trillion USD in this period. Between 2008 and 2012, 144 million people were forced to leave their homes as a result of disasters. ${ }^{3}$ [1: 10]

Nowadays, with the widening range of hazard factors, with the change in the nature and devastating effects of disasters, it is necessary to analyse all forms of prevention, meaning activities aimed at avoidance and preventing escalation. This research has not only aimed at identifying prevention tasks, finding results serving empirics, but also the theoretical investigation of the place of the prevention/preparation group of tasks in the protection system and the correlation of its system elements. Planning my research, I assumed that disaster management is an integral part of today's complex system of protection; its structure, subsystems show similarity therewith; there are identical phenomena in multiple places. I have also assumed that the fundamental areas of hazard factors and the prevention of disasters also show significant correlation, and their implementation at national, county and local levels are mutually interrelated.

During my research, I studied Hungarian and international literature with the method of document analysis, compared the subsystems of protection/defence system and their elements with the components of the system of disaster management. I have analysed the guidelines of international organizations regarding protection, the internal regulators of entities involved in disaster management and other protection organizations, as well as relevant legislation, furthermore, the disaster management activities of settlements. I conducted interviews with Hungarian defence and protection specialists; analysed some of the foreign examples of prevention and preparation; looked for analogies, I used the experience of my colleagues and my own professional practice gained in the protection/defence sector.

In order to identify and analyse the major cornerstones of the prevention of extraordinary incidents, we must look at factors influencing our security from this aspect and the protection system set up for security, define its subsystems and find a place for the tasks of prevention and preparation in them.

\section{Hazard Factors and the Responses to Them}

The design of effective protection against hazards is based on Hungary's vulnerability assessment. It determines the risk of occurrence and executes it along a planned, comprehensive strategy, and the toolbox for its implementation is the security policy used as the starting point.

The aim of security policy is to identify the fundamental values and interests in a given country. All of them in Hungary were laid down in the National Security Strategies. [2] [3] The definition of activities aimed at preventing extraordinary incidents affecting the safety

The United Nations has already devoted considerable resources to the fight against disasters and several actions and forums have addressed effective protection, such as the Framework for Action 2005-2015, the International Decade for Natural Disaster Reduction of 1989, the Yokohama Strategy for a Safer World, etc. 
of the country and the population is only possible on the basis of identifying the hazard factors. This can be done from multiple sources, so based on legislation, Hungarian hazard analyses, publications made from research in the field of protection/defence, as well as the analysis of basic security policy papers, etc. ${ }^{4}$ The identification is best done based on the National Security Strategy that identifies hazards. (Figure 1, Column 1) These factors have a different risk of occurrence, endangering our environment in a variety of ways. The protection against them has a wide range of activities, efficiency and effectiveness, which, as a result of the Hungarian protection system, also contributes to our participation in international organizations, collective protection/defence co-operation. The current National Security Strategy (NSS) - besides the list of hazard factors - mentions protection/defence activities as means of preventing them. (Table 1, Column 2) [3: Items 24-38]

Table 1. Hazard factors and the preventive protection activities against them according to NSS.

$$
\text { (3: Items 24-38) }
$$

\begin{tabular}{|l|l|}
\hline 1. Hazard factors & 2. Preventive protection/defence actions against them \\
\hline $\begin{array}{l}\text { Regional conflicts, } \\
\text { extremism }\end{array}$ & $\begin{array}{l}\text { Strengthen security policy relations based on mutual interests; } \\
\text { action to prevent crises, help stabilization. }\end{array}$ \\
\hline Terrorism & $\begin{array}{l}\text { Participate in international actions against terrorism; develop } \\
\text { an international counterterrorist organization system; prepare } \\
\text { for the emergency. }\end{array}$ \\
\hline $\begin{array}{l}\text { Proliferation of weapons } \\
\text { of mass destruction and } \\
\text { their means of delivery }\end{array}$ & $\begin{array}{l}\text { Further strengthen the international demobilization process; } \\
\text { assist in armaments control, multilateral diplomacy. }\end{array}$ \\
\hline $\begin{array}{l}\text { Security of financial } \\
\text { systems and processes }\end{array}$ & $\begin{array}{l}\text { No solution is proposed because it interprets public debt } \\
\text { as vulnerability. }\end{array}$ \\
\hline $\begin{array}{l}\text { Vulnerability of informa- } \\
\text { tion technology systems }\end{array}$ & $\begin{array}{l}\text { Risk assessment, proper operation of information and communi- } \\
\text { cation systems, government backbone networks. }\end{array}$ \\
\hline $\begin{array}{l}\text { Vulnerability of energy } \\
\text { systems and supply }\end{array}$ & $\begin{array}{l}\text { Protection of the operation of the national critical infrastruc- } \\
\text { ture. }\end{array}$ \\
\hline $\begin{array}{l}\text { Global climate and envi- } \\
\text { ronment change }\end{array}$ & $\begin{array}{l}\text { Build an integrated regional and European internal energy } \\
\text { market; find new purchasing and transit opportunities; pro- } \\
\text { mote renewable energies. }\end{array}$ \\
\hline $\begin{array}{l}\text { The effects of the weath- } \\
\text { er becoming increasingly } \\
\text { more extreme }\end{array}$ & $\begin{array}{l}\text { Increase flood and inland water protection safety, eliminate } \\
\text { health risks and epidemics. }\end{array}$ \\
\hline $\begin{array}{l}\text { Exhaustion of raw } \\
\text { materials and natural } \\
\text { resources }\end{array}$ & $\begin{array}{l}\text { Eliminate health risks, epidemics; maintain food and water } \\
\text { security; reduce pollution in the waters, accumulated in the } \\
\text { soil and subsurface. }\end{array}$ \\
\hline healthy drinking water \\
\hline
\end{tabular}

4 In a previous study I examined their content, relationships and the anomalies in the grouping of hazard factors, so I will not elaborate it in detail. [4] 


\begin{tabular}{|l|l|}
\hline 1. Hazard factors & 2. Preventive protection/defence actions against them \\
\hline Food problems & $\begin{array}{l}\text { Eliminate health risks, epidemics; maintain food and water } \\
\text { security; reduce pollution in the waters, accumulated in the } \\
\text { soil and subsurface. }\end{array}$ \\
\hline $\begin{array}{l}\text { Natural and industrial } \\
\text { disasters }\end{array}$ & $\begin{array}{l}\text { Increase nuclear safety and protection in Hungary; bilateral } \\
\text { exchange of information and cooperation with neighbouring } \\
\text { countries; extend the licensing and control activities; ade- } \\
\text { quately prepare/train professional disaster management enti- } \\
\text { ties, as well as other bodies involved in disaster management. }\end{array}$ \\
\hline $\begin{array}{l}\text { Arms, drugs and human } \\
\text { trafficking }\end{array}$ & $\begin{array}{l}\text { Close cooperation of criminal and law enforcement agencies, } \\
\text { justice and national security services, cooperation with EU } \\
\text { bodies; increase the efficiency of law enforcement; improve } \\
\text { the technical level and qualification of the personnel of the } \\
\text { relevant entities. }\end{array}$ \\
\hline Organized crime & $\begin{array}{l}\text { Reconnoitre the property background of groups; prevent the } \\
\text { legalization of their funds; develop criminal and prosecutorial } \\
\text { legislation; develop legal regulation preventing the influence } \\
\text { of organized criminal groups. }\end{array}$ \\
\hline $\begin{array}{l}\text { Appearance of extreme } \\
\text { groups }\end{array}$ & $\begin{array}{l}\text { Effective implementation of the enhanced protection of ex- } \\
\text { ternal borders; improve the cooperation of contributors in the } \\
\text { implementation of the Hungarian law enforcement and migra- } \\
\text { tion tasks. }\end{array}$ \\
\hline $\begin{array}{l}\text { Consolidate the use of force monopoly of the state; more } \\
\text { effective management of social and societal problems. }\end{array}$ \\
\hline
\end{tabular}

The preventive measures listed in the table are the first steps of prevention and preparation. The National Security Strategy_completed as a result of the security policy activity (Figure 1) - has provided the foundation for the creation of new protection/defence organizations and the adaption of the existing ones to the new security environments; they are the basics of safeguarding our security and achieving adequate protection/defence. ${ }^{5}$ The protection strategy is the protection system, established in a way fixed in legislation, adapting to the stipulations described here, and the triple unity of organizations and assets operated to guarantee our protection.

I interpret security here not as the absence of hazards, but as an adequate protection against them. 


\begin{abstract}
"is part of the government politics whose goal is to create external and internal conditions that are favorable for the protection of the essential national values."

(BUCZKÓ G.: Kelet-Közép-Európa biztonságpolitikája a NATO 1990-es bővitését követően. Budapest: Budapesti Gazdasági Főiskola, thesis, 2004.)
\end{abstract}

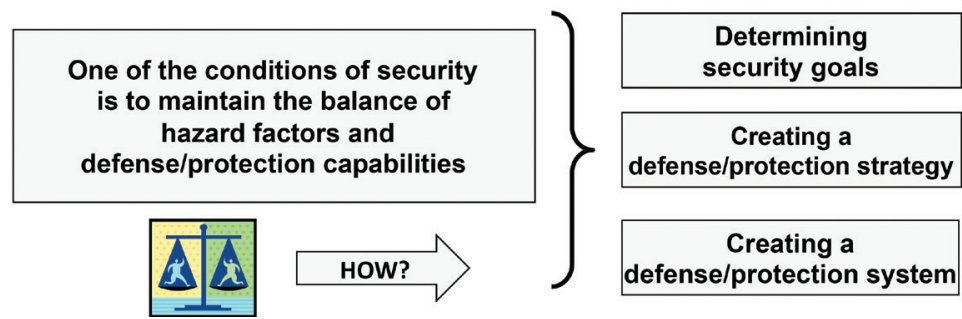

Figure 1. Goals and tasks of security policy. [5: 8]

There are some new hazard factors in addition to the earlier threats, but we also encounter specific variants of the traditional types as well. They have a wide range of effects, therefore, the protection/defence activity - such as the prevention and preparation task group, studied in this research — cannot be linked to a particular field of expertise, not even to the functioning of the complex system of protection/defence, because it goes far beyond: it is an all-societal task.

Effective protection presupposes the coordination of different systems performing activities in interaction with each other: in legislation and law enforcement, in the development of a protection/defence system and within the preparation; in the operation of different levels of protection/defence organizations and protection administration, as well as in the preparation of citizens and NGOs alike. I will outline its details later, under the heading Preventive Protection.

\title{
Components and Special Features of the Protection System
}

It can be seen in Table 1 that from the tasks to be carried out in the interest of security, the examination of the definition of security objectives or goals is not relevant to the present study or the formation of the protection strategy, but the analysis of the Hungarian protection system and its features are important. I will analyse the relevant legislation and security policy documents based on this.

\section{Components of the Protection/System}

The system of protection was developed in Hungary based on the principles of complexity and the comprehensive approach. [4: 107-109] In this context, the system of protection consists of distinguishable independent elements and fields. Beyond this, it has a peculiar function. (Figure 2) 
The elements of the protection system is society itself, accepting and requiring the protection demands, public administration prepared for protection (in given case: protection administration), entities and institutions of the defence economy, civil protection, armed forces, law enforcement entities, other entities participating in defence and the contributing population. However, after the period following the appearance of the interpretation of sectoral security, the creators of the system have striven for complexity not only considering the structure, but also its intended function.

The basic function of the system is to be able to manage extraordinary incidents, may they be of any nature, and even in such cases to be able to ensure the functioning of the state and local government administration and vital systems, to create protection-targeted reserves, the country's and population's security is at stake, to prepare the population for the hazards and the protection against them, and to ensure the conditions for life.

Another responsibility is that the protection of the population and essential material assets be viable (civil protection task), the armed forces, law enforcement agencies (including the professional branch of disaster management) and other entities involved in defence be available. They should be well-prepared and deployable.

The main fields of the protection/defence system are the system tasks of armed defence and civil protection. The tasks of armed defence are implemented in case the need arises to defend the country through armed defence and in case of the development of crises of military character. The tasks of civil protection are implemented in case of disasters or if non-military type of crises appear.

The complex system of protection/defense of Hungary

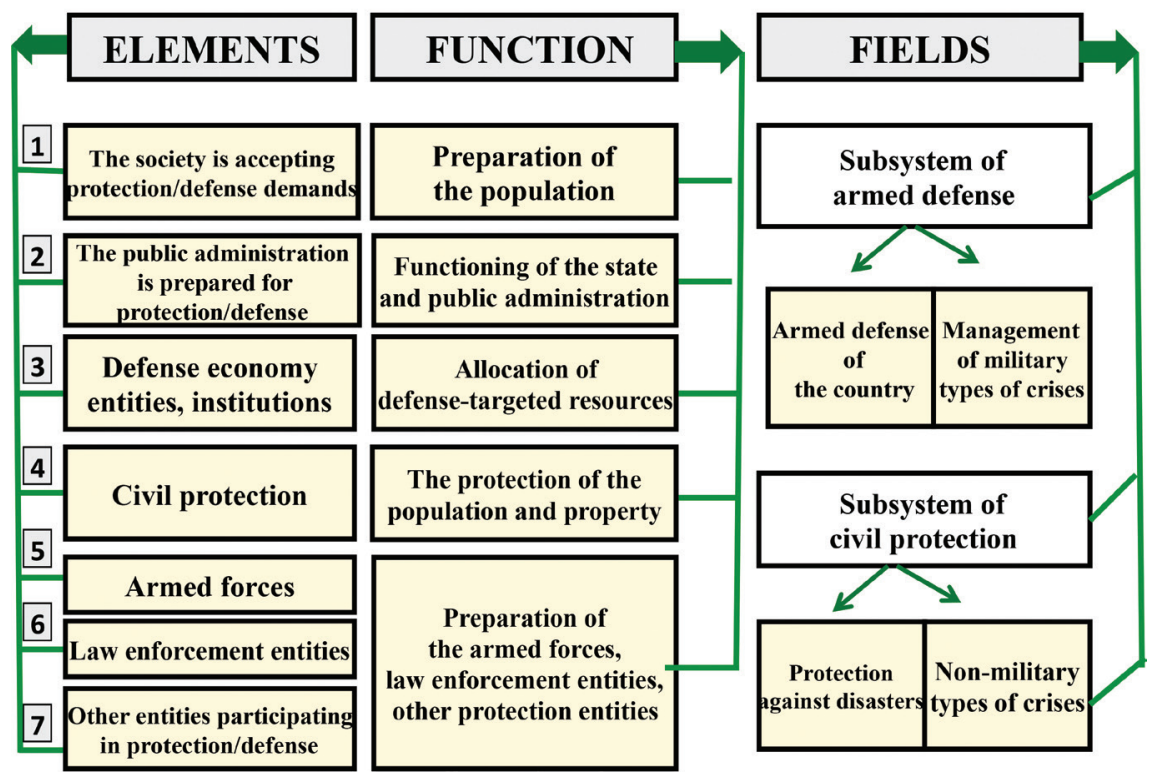

Figure 2. Elements of the complex system of protection/defence of Hungary, its function and fields nowadays.

(Created by the author.) 
There is a question as to how these elements and the protection tasks are linked to each other, what the complexity of the system is, and what basic features it has.

\section{The Systems Nature and the Subsystems of the Protection System}

The countries of Europe-with the disappearance of the bipolar world order-redrafted the security interests, objectives. Then security policy analysts and specialists in the protection sector took a "snapshot" of the hazard factors which are constantly monitored; these together formulated the possible trends.

Accordingly, the formulation of the expectations concerning the protection, the creation of the legal background and the change of existing system elements (subsystems), furthermore the establishment of new protection/defence organizations sector has taken place in Hungary.

\section{Subsystems of the Complex System of Protection}

Analysing the structure of the system, it can be ascertained that it has subsystems that may be grouped, according to different aspects. By the nature of hazard factors and from the aspects of responses to them, we distinguish subsystems: the already mentioned armed defence and civil protection. However, analysing it from the angle of implementation, we can speak of subsystems of tasks, organizations/institutions, and resources. The subsystems of the protection system, their main elements are summarized in Figure 3. Let's examine them!

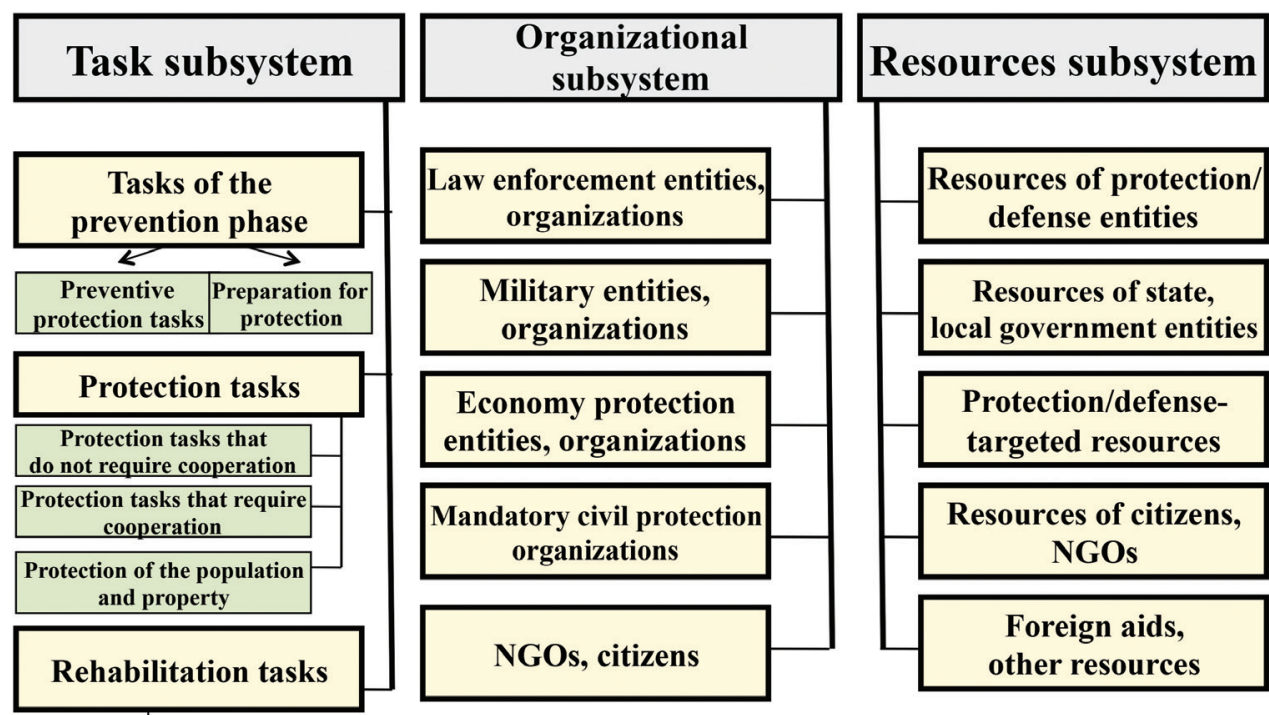

Ensuring the normal functioning of systems, establishing living conditions, territorial rehabilitation

Figure 3. Subsystems of the complex system of protection/defenceand their elements.

(Created by the author.) 
Analysing the task subsystem of the protection/defence system, it can be stated that it has several elements, such as prevention and preparation tasks, protection/damage mitigation tasks of an incident (independently from their nature), and after responding to an incident, the tasks aiming at ensuring rehabilitation and flawless operation. They basically depend on the sectors providing the environment of the protection/defence system, the geopolitical situation, the expectations necessary for performing alliance obligations, the hazard factors and their effects. The tasks are implemented in three phases: the phases of prevention, protection/response and rehabilitation.

- Prevention phase: the main group of tasks, which are implanted in order to be able to avoid a hazard, or to prevent its consequence(s) (prevention, avoidance tasks).

- Protection/response phase: the tasks are to be performed if (despite prevention) the effects of the hazard factors develop. We distinguish three main groups:

1. The first group is made up of tasks that must be performed if the incident, due to its character, is such that it can be managed by the responsible protection/defence organization on its own, without the need for cooperation.

2. The second group is characterized by the fact that they can only be resolved through the cooperation of organizations and responsible entities.

3. The third group is made up of tasks aiming at the protection of the population and the essential material goods.

- The group rehabilitation tasks constitutes the third element of the task subsystem. It can be divided into three further categories: the tasks aiming at the normal functioning of the systems, sustaining the conditions for life and territorial rehabilitation.

Examining the institutional/organizational subsystem of the protection system, we may say that it has been designed in accordance with the security environment and is basically made up of home defence/military, law enforcement, civil protection, and economy protection entities, organizations. They carry out their duties in a tight context with the system of protection administration (e.g. disaster management, home defence administration). ${ }^{6}$ The establishment of the protection system is a state responsibility; the organizational subsystem mainly consists of state entities and organizations. However, because the implementation of tasks is all-societal, NGOs, humanitarian organizations and citizens are involved in it as well. ${ }^{7}$ Each element of the organizational subsystem, due to its purpose, has basic tasks, fixed in legislation, but additionally they contribute to the provision of the core tasks of other institutional elements and in the resolution of extraordinary incidents, too. ${ }^{8}$

Due to the systems approach, any changes in an element will have an effect on the other one.

$6 \quad$ Home defence administration: "System of tasks and organizations forming a part of defence administration, within which entities established for the protection of the country, as well as public administration entities assigned to this task, as well as other entities, contributing to national defence perform the tasks stipulated in paragraph (3) of Section 1 of the Act on Home Defence on the training and preparation of entities defined for home defence, by the defence of the country and fulfilment of home defence obligations.” [6: para 1 (b)]

7 The participation of citizens may be voluntary, but may also be based on citizen's obligation, such as compulsory military service or civil protection obligation. [7: para 1 (3)]

8 The basic function of the Hungarian Defence Forces is e.g. “the military defence of Hungary’s independence, integrity and borders, the fulfilment of joint defence and peace-keeping tasks, originating in international treaties, and in harmony with the rules of international law, the performance of humanitarian activity." [8: Article 45 (1)] Beyond this, it participates as a cooperating entity, e.g. in fulfilling disaster management tasks as well. In detail see: [42] [43]. 
Examining the third component of the protection system, the resources subsystem can be ascertained that it is also composed of several sources, which are the following:

- own resources of entities, organizations participating in protection, including state, municipal entities,

- protection-targeted reserves, including citizens, NGOs,

- foreign aid and other resources.

Their application, the coordination of deployment and the allocation are coordinated by the Government and the protection committees, depending on the nature of the task and the activities necessary to restore normal life.

\section{Features of the Protection System}

I will outline the general characteristics related to all elements of the protection system. Examining the protection documents and legislation related to this, the features may be summarized as below:

- Hungary is a member of the United Nations, NATO and EU and other international organizations and it assumes the values thereof. It adheres to and enforces the principles of the United Nations Charter, takes an active role in crisis management operations of international organizations, so the defence/protection system should also be able to contribute to these tasks.

- When the protection/defence system currently in place was designed, the hazard factors, the features of the existing entities and organizations, the operational and procedural rules emerging in the past, the financial resources of the country and the expectations of international alliances had to be considered.

- Main considerations of the formation of protection/defence as central procedural, control and system requirements should prevail.

- The legislation accurately stipulates the obligations, tasks, entities, organizations, powers and jurisdictions; the order of control, enforcement and cooperation, and the bearing of defence costs in the protection system.

- The subsystems of the system are self-contained, they themselves constitute a complex entirety, but integrate organically, each of which represents added value.

- The system is hierarchically structured, consisting of several subsystems that are subdivided into elements. They can be subdivided into additional "element-specific" groups.

- Some of the tasks in the system can be performed in the normal legal order, but there are cases that necessitate the activation of the defence administration system and the introduction of a state of special legal order.

- The implementation of protection tasks take place under the principle of subsidiarity and if that is inadequate, the principle of assistance and other elements of the system are activated. There is a fundamental expectation of concentrating and planning the use of resources.

- Depending on the nature of tasks, cooperation not only within organizations, but between each other. It has paramount importance that they know each other's work, organization, the order of operation, and their coordination. 
- By today, sustainability and cost-effectiveness are gaining a momentum both in the formation, operation of the organizations and in the implementation of tasks, so prevention plays a prominent role in the system.

Their analysis by a scientific method, the investigation of the hazard factors and their polarization is timely due to the change in the recent period of public administration and the protection system. The extent of this article does not allow me to look at the activities that aim at avoiding all the above-mentioned factors, so I will emphasize the prevention of disasters and the preparation for their effects. (Table 1, Item 12: Natural and industrial disasters)

\section{Disaster Management Subsystems and Their Place and Role in the Complex System of Protection}

Analysing the protection system demonstrated above, I have ascertained that the subsystems can be defined in several ways. Examining the nature of the tasks to be performed, the protection system can be divided into the subsystem of armed defence and civil protection. ${ }^{9}$ (Figure 2) One of the areas of the subsystem of civil protection is the protection against disasters.

The prevention of disasters and the protection against their effects is an all-societal issue, stipulated by law, the implementation of which is done in a unified system of disaster management. ${ }^{10}$ The questions arise: where is the disaster management in the complex system of protection? How is it built up? How are the disaster management tasks implemented?

\section{The System and Subsystems of Disaster Management}

The tasks of the protection against disasters are implemented in the framework of disaster management, ${ }^{11}$ which belongs to the civil protection subsystem. (Figure 4)

9 In addition, there is an important task of civil emergency planning. Its aim is to decide how the armed forces should participate in solving the issue during civil emergencies or in case of war, and how civil forces should be involved in the protection of the population and property.

10 The uniform system of disaster management is not identical with the professional disaster management entity, whose development became finalized and uniform by becoming state-owned and controlled, by concentrating the forces, assets and capacities, by making the fulfilment of tasks more efficient, because other elements and entities are also part thereof.

11 Let us disregard the dispute going on for a long time in professional circles (in Hungarian literally "it is not possible to protect a disaster"- - a dilemma in the Hungarian terminology) relating to the semantical and syntactical correctness of the word, because nowadays, this concept has become accepted; during its scientific interpretation, we may abstract from the "mixed metaphor" derived from the peculiarity of the Hungarian language. 


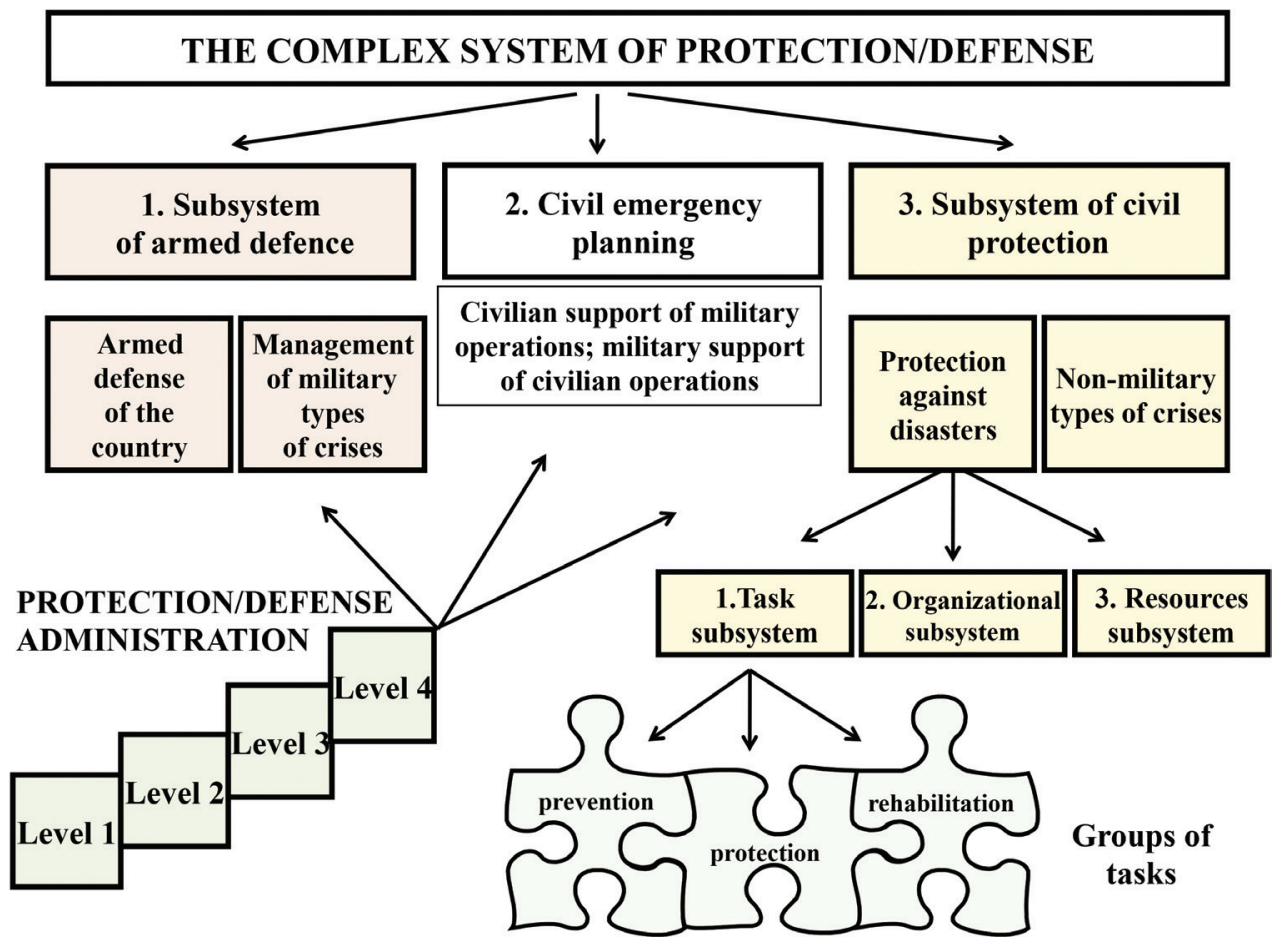

Figure 4. The place of the protection against disasters in the complex system of protection/defence.

(Created by the author.)

It can be seen from Figure 4 that the structure of the system of disaster management and its hierarchy is similar to the one of the complex system of protection. The protection against disasters itself is an independent unit ${ }^{12}$ and can be divided into subsystems. These are the following:

- hazard factors and the implementable disaster management task subsystem,

- organizational and institutional subsystem consisting of implementers,

- resources subsystem necessary for implementation.

The first subsystem of the protection against disasters is made up of groups of tasks which must be carried out in the phases of prevention, preparation, protection/response and rehabilitation. $^{13}$

Although the tasks of a given phase are named after the given phase, however, it is important to note that the tasks of prevention and preparation are not exclusively performed in the prevention phase. In the phase of protection, it may be necessary to fulfil the tasks that serve rehabilitation, that is, the tasks that are not only linked to their own phase. The goals and the implementation methods of the groups of tasks are shown in Figure 5.

12 Under disaster management in this context, one should understand a system and not an organization.

13 Regarding their nature, according to the classic categorization, these tasks may be civil protection, fire safety and industrial safety. 


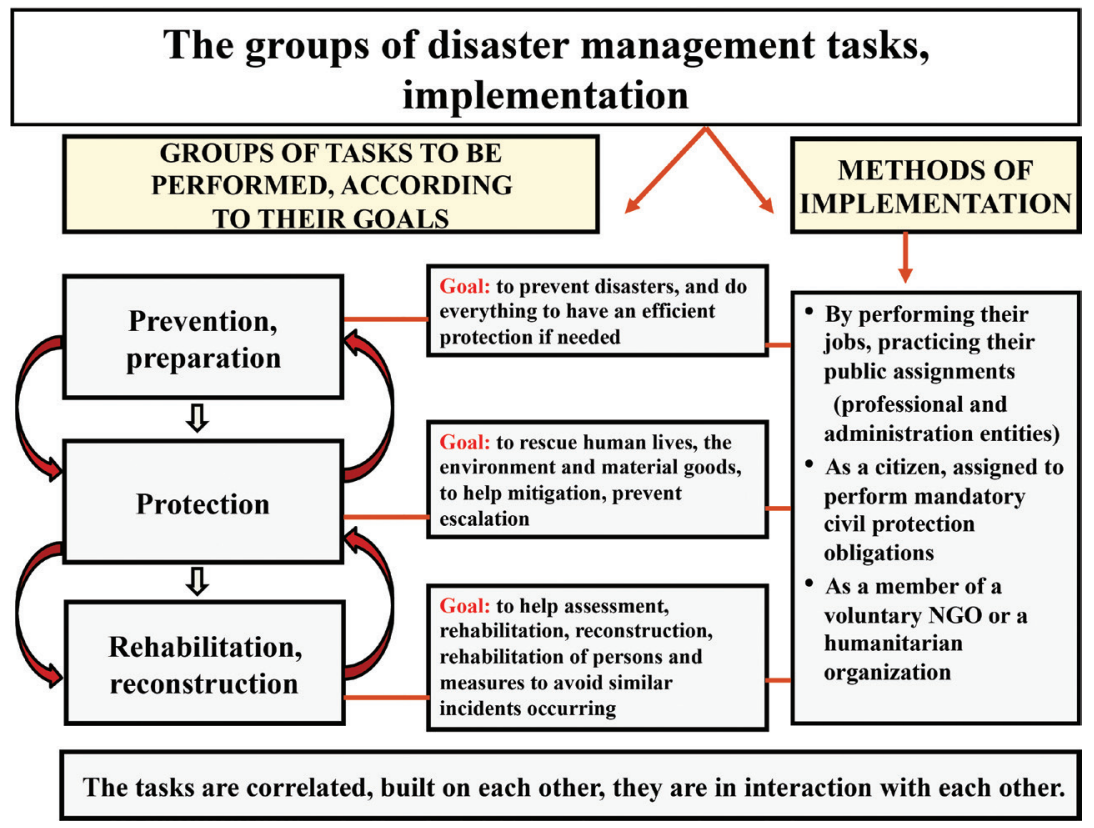

Figure 5. Groups of disaster management tasks and the methods of their implementation.

(Created by the authors.)

In the system of disaster management, given the organizations and institutions, the scope of contributors is wide. Entities created for protection and for eliminating the consequences of disasters are the professional disaster management entity ${ }^{14}$ and the mandatory civil protection organizations. ${ }^{15}$ However, according to the law, additional elements also participate in the implementation of tasks as contributors. [9: Section 2 (1)]

The resources to perform disaster management tasks are included in the resources subsystem. They originate from several areas. The resources provided by them and the ones created from the reserves of contributors, and on the other hand, state, local government protection reserves and the resources of citizens, NGOs and humanitarian organizations belong to this group. Protection and rehabilitation and the measures to ensure life subsistence are also supported by Hungarian and international assistance and aids.

As a summary, it can be stated that disaster management is an integral part of the complex system of protection/defence and is included in the group of civil protection tasks. Its structure shows a match with the complex system of protection, its system characteristics are

14 National Directorate General for Disaster Management, Ministry of the Interior, and its county and settlementlevel entities.

15 Civil protection obligation is a citizen's obligation, which includes data provision, reporting, appearance and civil protection service. Under this obligation, citizens may be assigned to civil protection organizations. For the sake of an intervention necessary for disaster prevention, and in an emergency, a person assigned to a civil protection organization may be ordered to fulfil temporary civil protection service. These organizations may be central, territorial, settlement-level and workplace civil protection organizations. [9: Chapter VI] 
detectable, and there is the division of tasks, organizations and resources. They show interaction with each other and with other elements of the protection system. The formation of its legal background fits it into the legal environment of the protection/defence system. Among these tasks, prevention and preparation play a prominent role.

\section{Goals, Basic Fields and Main Group of Tasks of the Prevention of Extraordinary Incidents}

The experience of the past decades shows that eliminating the effects of extraordinary incidents, the protection against them can only be effectively performed in the phase (prevention) before it occurs, minimizing the chances of its development, and in parallel, we prepare to perform all the tasks that are needed to be done in a possible protection operation.

The goal of the prevention phase is to implement all legal, technical, investment, training, preparation, resource allocation etc. tasks, activities, with which the occurrence of extraordinary incidents can be prevented or their adverse effects can be reduced, and which, if necessary, increase the effectiveness of protection tasks and minimize escalation.

\section{The Basic Fields and Main Groups of Tasks of the Prevention of Extraordinary Incidents}

The types of extraordinary incidents and their effects are complex, the principles and methods of protection against them are diverse, however, there are general prevention considerations, requirements and tasks that are applicable and can be extended to any hazard. I summarize them below.

\section{Definition of International and Hungarian Protection-Targeted Guidelines Objectives}

The framework directives of international organizations (UN, EU, NATO, OSCE, ${ }^{16}$ etc.), such as the UN INSARAG ${ }^{17}$ Guidelines or the NATO doctrines belong here. The protection/ defence objectives are defined in the National Security Strategy of Hungary, the Military Security Strategy and the various sectoral guidelines.

The inclusion of protection/defence-targeted requirements, obligations and tasks in legislation

Legislation, provisions, measures aimed at the prevention and elimination of extraordinary incidents belong here, but those acts may also be included here that define the establishment of organizations necessary for protection and the management of protection clarify the powers and competences, regulate the conditions of implementation and name the required forces and assets.

\footnotetext{
16 Organization for Security and Cooperation in Europe

17 International Search and Rescue Advisory Group
} 


\section{Planning and implementing preventive protection investments, territorial arrangements}

Definition of settlement development plans, protection-targeted requirements of investments, planning the location of hazardous industrial plants, reducing transportation vulnerability, raising its resilience, planning the dimensions of roads and bridges aligned with protect goals, building utilities, power supply with multi-directional feed, etc. are included here.

Definition of the protection-targeted requirements of different sectors (energy systems, industrial and agricultural activities, etc.), the establishment of legal requirements for the implementation and the coordination of implementation are also part of this area.

\section{Protection planning}

Amongst others, the drafting of preventive protection plans for the protection against extraordinary incidents can be listed here. Their goal is to determine all the tasks, criteria, assets and manpower needs which may ensure the efficient implementation of prevention and the tasks of protection. The protection plans primarily contain the strategic and tactical tasks of national or regional levels and their criteria which appear on a local level in the emergency management plans of settlements. ${ }^{18}$ The basis of protection plans are vulnerability assessment, risk identification and the determination of the necessary protection level.

\section{Establishing the organizational, human resources, material and technical resource needs of protection}

Among others, the acquisition and existence of human and material resources, the technical equipment necessary for the establishment of entities, organizations involved in protection and their maintenance for protection activities can be listed here. Central and local protection kits, materials, tools, instruments, resources, indispensable for population protection tasks and damage mitigation belong to this area. Those technological developments should be developed here which serve the creation of various procedures required during protection: metering networks, monitoring systems, software, instruments, etc.

\section{Training and preparation}

The creation of the conditions of training and preparation required for the prevention and protection against extraordinary incidents can be listed here. Their goal is to prepare the participants in protection to carry out their duties of participating in the development of the conditions of training and preparation tasks required for the self-protection capabilities of the population, furthermore, to prepare entities and persons performing protection duties in the state and public administration fields.

18 Nuclear emergency management plan, plan for armed defence, the protection plans of the county protection committees, environment protection plans. 


\section{Preparation for the Prevention of Disasters and the Protection against their Effects}

The hazard factors endangering Hungary and its citizens, based on the National Security Strategy, have been demonstrated by me in Table 1. Then I examined the complex system of protection, and within the system of disaster management and their correlation. Now I analyse the basic areas of disaster management with a similar deduction method, in relation to prevention tasks. Its starting point is matching the areas of prevention to disasters, as demonstrated in the previous subchapter.

\section{Groups of Tasks Aimed at the Prevention of Disasters}

\section{Acceptance of international protection-targeted guidelines, the formation of Hungarian objectives of protection against disasters}

The prevention tasks are defined by the Hungarian National Assembly following the recommendations of international organizations involved in the protection against disasters and their guidelines, based on Hungary's vulnerability. They are implemented through the protection administration system. Since their establishment, international organizations (UN, EU, NATO) have been dealing with protection against disasters and have developed guidelines, framework programs, action plans, ${ }^{19}$ which are joined by countries. By taken into account the vulnerability of their own territory, they develop their national disaster management strategies both for prevention and for international engagement. For instance, at the $3^{\text {rd }}$ UN Conference in Sendai, in 2015, a framework was published, titled Sendai Framework for Disaster Risk Reduction, ${ }^{20}$ which emphasizes the importance of prevention. [10: 13 Item f]

\section{Introduction of protection-targeted requirements, obligations and tasks in legislation to prevent disasters}

The basic legal background of the protection against disasters is provided by, for example, the Act on Disaster Management, the Decree on its implementation and various Minister of the Interior decrees, providing the framework of the implementation of the different tasks. [9] [10] [11] In addition, legislation includes the main tasks of disaster management on the different levels of protection administration and their principles, methods and tools. In connection with preventive disaster management tasks, the legal provisions define different professional specifications and obligations. For example, they regulate the order for the setup and operation of disaster management in Hungary, and in this relation, the tasks of the government, county and local protection committees and mayors. They stipulate the

19 Such are for instance: The Hyogo Framework for Action 2005-2015: Building the Resilience of Nations and Communities to Disasters; Framework for Action for the International Decade for Natural Disaster Reduction of 1989; Yokohama Strategy for a Safer World: Guidelines for Natural Disaster Prevention, Preparedness and Mitigation and its Plan of Action; International Strategy for Disaster Reduction of 1999.

20 In this it is emphasized that the development of technology and research, furthermore, significant steps should be taken in the field of installing early warning systems as well, thus increasing the resilience against disasters. One of its criteria is the cooperation with international organizations and with each other; in order to do so, the conditions for the flow of information must be created. [1: 11 Item 14] 
obligations of citizens, preventive protection duties of public administration, the country's vulnerability classification, the vulnerability categories, and the setup of protection levels associated with it. Legislation provides for sectoral disaster management tasks, its protection-targeted requirements for settlement plans, the establishment of central resources, the principles and requirements related to the operation. The Government (based on these laws) defines, for example, the duties of government members and state entities in dealing with protection, related to disaster management, the planned amount of appropriations that may be used for Hungarian and international assistance, provides financial support for the operation and development of disaster management. [9: para 5] [9: para 10] [9: para 14] It also provides for the protection administration tasks to be implemented by public administration. For example, the county, Budapest and local protection committees manage and coordinate prevention-focused tasks based on the above, and prepare the tasks of entities affected in disaster management.

Here, the followings may be listed: the specific regulations of the organizations involved in disaster management and elimination, as the MoD decree defines the establishment of the scope of home disaster management and protection systems. [12]

\section{Implementation of preventive technical protection investments, territorial arrangements}

The goal of this group of tasks is to prevent disasters from occurring and to reduce their possible effects in the framework of which it is expedient to perform the following major tasks:

a) At national level, various preventive technical protection tasks and measures should be implemented by the sectors.

b) When drafting settlement development and arrangement plans, protection considerations must be enforced, and in the framework of a specialized authoritative activity the disaster prevention tasks and rules must be enforced.

c) The structure of the public utility network and industrial arrangement of settlements must meet the criteria of protection targets that serve to prevent any accident concerning the transportation and storage of hazardous materials. ${ }^{21}$

d) The placement of industrial plants and food businesses is essential for the subsistence of the population in a safe distance from each other.

e) Multilateral energy supply, protection-targeted investments, installation of water resources, dams, dykes, reservoirs, monitoring and alarm systems.

f) Designation of essential material goods and facilities, definition of their vulnerability and ensuring their preventive protection.

21 Major special authoritative activities in the system of disaster management nowadays are: fire prevention, (ADR: Accord européen relatif au transport international des marchandises dangereuses par route; ADN: The European Agreement concerning the International Carriage of Dangerous Goods by Inland Waterways; RID: Regulation concerning the International Carriage of Dangerous Goods by Rail; ICAO/TI: International Civil Aviation Organization/Technical Instructions for the Safe Transport of Dangerous Goods by Air), activities in connection with the transportation of hazardous materials, the protection of vital systems and facilities, control of chimney sweeping public services, special authoritative activity in connection with constructions, special authoritative activity in connection with settlement planning and arrangement. [14: Slides 26-27] 


\section{Emergency management planning}

Based on national and regional protection plans, local emergency management plans must be drafted. The setup is based on the vulnerability assessment and analysis and the protection classification of settlements. Using this, the required level of protection must be defined in the settlement plans: the number of staff; the structure of protection organizations suitable for the material and technical needs; the form and manner of alert and standby/ duty; as well as the time of deployment standby. Plans must include the amount and location of reserves required for the establishment and operation of organizations involved in protection.

\section{Ensuring the organizational, human resources and technical-material resources needs of protection}

Disaster management entities play a prominent role in planning, organizing disaster management tasks. The Ministry of Interior and the professional, but other ministries, organizations and entities are also involved in their own areas. The establishment and the number of organizations, the provision of human, material and technical conditions for the operation are segregated in the budget chapters of a given ministry. Providing the conditions necessary for the performance of its professional duties and protection, depending on the nature, magnitude and location of a disaster, originates in the state framework, the stocks of settlements, facilities, resources of businesses and their entirety.

The technical upgrades and the setup of monitoring systems are state tasks; their locations are determined by professional disaster management; testing and corrections are made based on their suggestions.

\section{Training and preparation}

Ensuring organizational, human resources, material and technical conditions and preparation altogether provide the protection capability of a settlement, which not only represents the prevention capabilities, but also necessary for protection. ${ }^{22}$

\section{Up-To-Date Methods and Means of Prevention and Preparation}

The aspects and tasks outlined above provide a framework for the implementation of prevention, but the specific tasks of implementation depend on the type of disaster. In Hungary, we must count with the emergence of both man-made and natural disasters. The extent of my article does not allow the analysis of all these, so I will highlight only two types. I have searched for up-to-date methods in academic research and in the protection practice for their prevention and the avoidance of their escalation.

22 "Under protection capability, all planning, organizing, implementation activities, rules, and the entirety of forces and means should be interpreted, which ensure the prevention of the occurrence of hazards, the rescue of the lives and property of the population, the mitigation of damages, the avoidance of further hazards, the establishment of basic living conditions, and the support of the professional rescue forces.” [4: 73] [15: 104] 


\section{Up-to-date methods to prevent wild fires and the tasks in relation}

The protection against wild fires has also attained the attention of scientific research. [16] [17] More and more professionals are involved in developing new, more effective procedures for preventing the propagation of fire. In doing so-beyond the further development of traditional methods-we encounter new solutions.

Below, I will present some examples in order to ensure the effective implementation of preventive protection tasks, what scientific achievements and technical upgrades occurred that may be utilized in practice as well.

General preparations include the identification and control of fire hazardous activities and re-regulation of the forms and methods of their implementation. The prevention of the propagation of fires, the drafting of the prevention of wild fires and the preparation for extinguishing them; the purchase of equipment, the creation of conditions necessary for extinguishing fires and the maintenance of the applicability of assets. In order to implement the above, modern GPS devices and GIS systems assist in situation analysis, and risk analysis is also applied. It is important to know how to use them, to be trained for them. [18: Slide 4] [18: Slide 9]

Developing programs for predicting fire propagation was also focused on by IT researches. The researchers of the Lawrence Livermore National Laboratory, Los Alamos National Laboratory and Atmospheric Release Advisory Centre started to upgrade existing programs for predicting fire propagation by linking geographic parameters, weather factors and smokecloud propagation programs. They are able to optimize the time factor, reduce the vulnerability of humans, animals, and valuables. [19: 158]

Arnie Heller reported on the upgrade of the method in the FIRETEC simulation model that further developed the program to enhance the characteristics of combustion and other factors influencing the propagation of fire as well, such as its type, composition, combustion properties of the vegetation, etc. Nowadays, a newer version of the model has also been completed (HIGRAD FIRETEC), which already takes into account the possible ways and the characteristics of spark and foliage fire propagation and thus can provide a more accurate propagation forecast. By using it in the preventive phase, it is possible to more successfully prepare for what can be expected in a given situation. [20]

Stefan Patzelt-based on the analysis of hundreds of fires-drew conclusions and regards of prominent importance: the length of time between the detection of and the response to fires. He proposed new methods of fire detection, which advocated the deployment of fire watch towers and the design of the Firewatch System. There is an optical rotating camera system capable of detecting 16,000 grey colour change values in a distance of $10 \mathrm{~km}$, in an area of $314 \mathrm{~km}^{2}$ and can transmit these signals to the centre in a fire tower. The image analysis program that is located there evaluates the images; and is able to detect the smoke column at a distance of $10 \mathrm{~km}$, identify its characteristics and alert the response units.

Additionally, the researcher considers it important to use simulation fire extinction programs in practice in order to detect the possible fire hazards, especially to reconnoitre inaccessible locations in time as well as the preparation for aerial firefighting. All these would create an opportunity to detect the factors that hinder firefighting, trace natural and artificial water sources, and learn about deployment schedules needed for extinguishing. [21: 167] 
In practice, the use of drones is spreading more and more in airborne reconnaissance. They can be used effectively in many areas, such as exploring fire hazardous locations, detecting fires, mapping locations of firewalls and exploring a flammable environment for risk analysis. Photographs and video footage made by drones greatly help the efficiency of detection. [23] [24: 19]

To reduce the propagation of fires, in addition to traditional methods (extinguishing with water or foam, creating blocks on the terrain to stop the propagation, etc.) we are also encountering new solutions. Such are the so-called retardants, containing flame retardants consisting of water, dyes, ammonium salts and silicon or rubber. They are made up of aluminium sulphate and aluminium phosphate which - when mixed with water-have not only fire retardant and heat-reducing effects but also (by their colour) they serve as good indicators for aerial firefighting operations as to where the extinguishing has already taken place. [21: 48] Today many new versions are known, ${ }^{23}$ and much research is underway to modernize them. [25] [26]

\section{Up-to-date methods and tasks of flood and inland water prevention}

Hungarian and foreign experts and researchers are constantly analyzing the trends of developments and the devastating effects of floods, examining modern prevention options and upto-date protection principles. They develop methods and make proposals on how to upgrade and use the equipment. [27-34] [44] Up-to-date methods of preventive flood control are summarized below.

One method is to design and upgrade flood protection levees. Based on practical experience as well as on research results, the transformation of the floodplain of river sections becomes necessary, in which the design, construction, heightening of new levees is performed through modern methods and can be relocated as needed. Beyond the above, it is an important task to protect existing dykes. It has been proved in recent years that the protection of levees can only be solved in complexity, in which the structure of the dyke itself (soil-binding plants, compression, elimination of holes caused by animals, etc.) should be taken care of. Furthermore, protection is needed against the saturating effects of inland waters that is appearing more and frequently. One method of this is the combination of dyke protection with protection against inland waters.

The protection against subsurface water in the vicinity of the levees can be implemented by draining. The essence is that with the help of a closed water drainage system-consisting of a suction, sub-collection and main collection pipeline, or a simpler version thereof-an open system can be developed which is ending in a canal, so the water can be discharged from the ground in the vicinity of the levee. (Figure 6)

Further points can be made on the tasks of riverbed and floodplain control. The solutions that provide rapid and unobstructed access of flood waves to the riverbed or (where necessary) the protection of dykes also serve to drain flood peaks into floodplains, and belong to the preventive flood protection tasks. There are many technical solutions to this, of which I highlight the followings:

- the increase of area of the floodplain by moving or heightening the dykes,

- the transformation of river control structures as needed,

${ }^{23}$ E.g., Phos-Chek 259, types G75, P100. [22] 
- the deepening of main riverbed and side branches by dredging,

- the removal of summer dykes and levees, buildings and other facilities from the floodplain. [36]

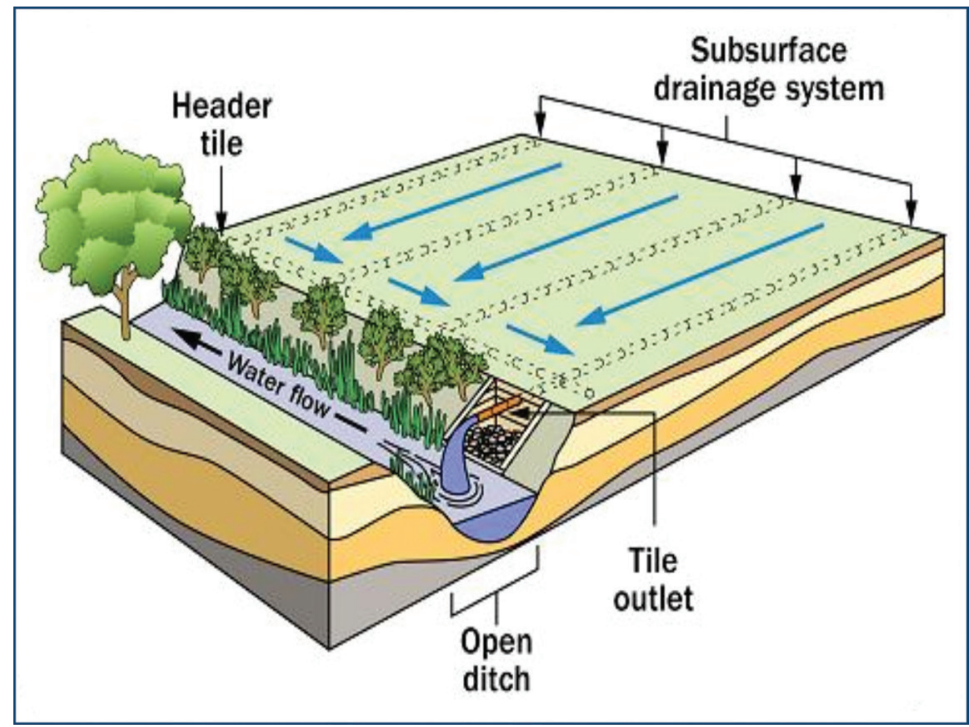

Figure 6. Ground water discharge with drainage technology. [35]

Another possible way of protection is the construction or upgrade of reservoirs, which are designed to prevent the flood from damaging existing flood protection structures and not compromising settlements and farmlands. If necessary, the drainage of flood peaks takes place in them, later the water will be pumped back to the riverbed or used for irrigation. Nowadays, we have many up-to-date building technologies and materials for the construction of reservoirs. For smaller reservoirs soil-strengthening geogrids, insulating geotextiles and foils are often used.

It is crucial to use advanced dyke systems. The basic function of a dyke is to stop the water from flowing, built parallel or across the water stream, to protect the area behind it. In previous years, one of the methods of preventive protection was to strengthen and heighten existing dyke and levee systems. Various solutions have come to be used, such as heightened temporary levees, and so on. Nowadays, the use of a new type of so-called mobile dykes is spreading more and more. Its advantage is that it can be purchased in the precautionary phase and can be stored centrally, and can be installed and disassembled in a short time after a flood. [37]

The following images are of mobile flood protection walls. They consist of fixable pillars, filling elements made of glued polyethylene and polyurethane to the pillars, water tightness is provided by hollow profile rubber and clamp sliders. [38]

The "Quick-damm" is a type of mobile dyke that can be quickly installed. There are several types. A common element in them is the light geo-membrane fixed to a metallic frame; it consists of pieces to be built together, filled with sand. 


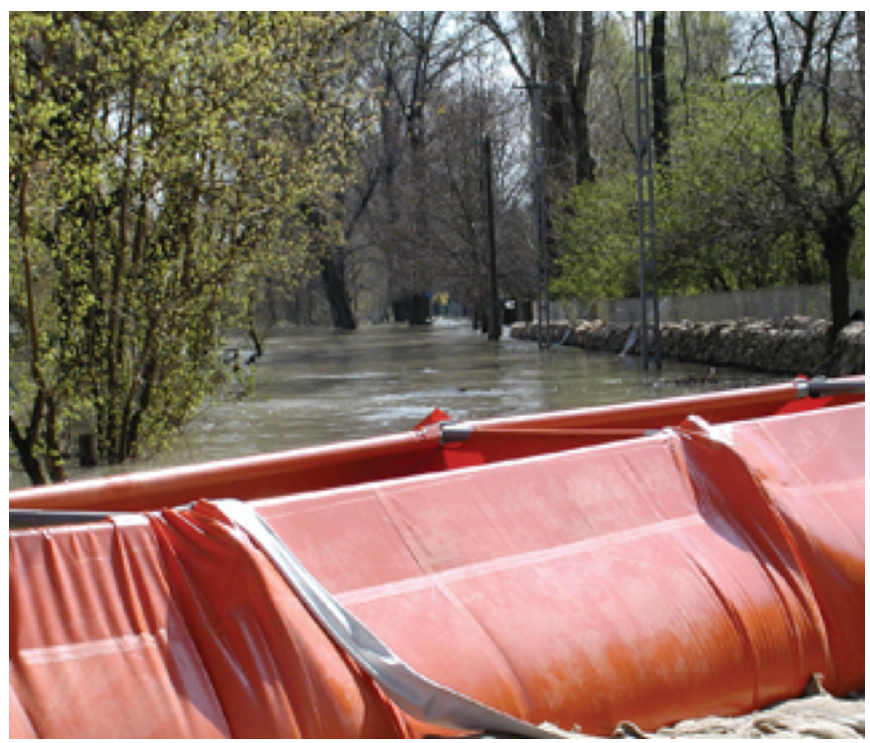

Figure 7. Quickdamm. [39]

A new development is the so-called Aquariwa, which, due to its dimensions (length: $4.1 \mathrm{~m}$ ) and materials (fiberglass, elastic, swivel, plastic) can be faster deployed and has a great tensile strength and it can be relatively easily emptied after a flood.

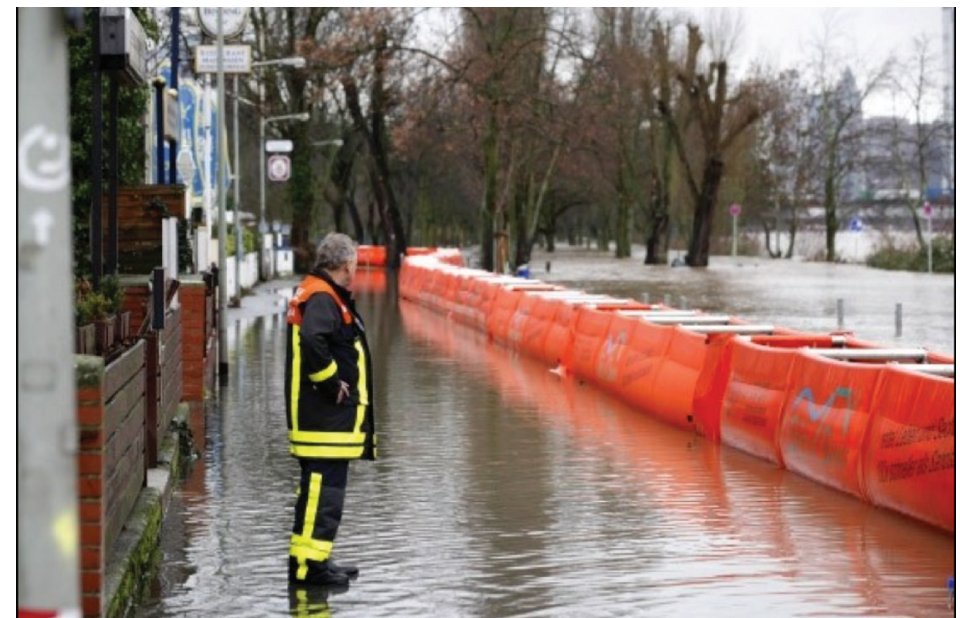

Figure 8. Rapid-deployment mobile dykes. (Made by Dapd, [40])

In addition to technical solutions, it is important to have a fast and reliable forecast as well as response to the signals. Among the prevention tasks, the installation and operation of modern alarm systems is of paramount importance and also the creation of an IT background necessary for this. For example, there is a common, integrated, real-time hydrological forecasting system on the Ipoly River in Hungary. [41] 
The magnitude and extent of the damage by a flood depends largely on how we can prepare for the protection against it, which is dependent on the time available. The preparation is heavily assisted by flood control simulation programs which have spread over recent years. These can be updated with interactive maps to improve damage prevention and mitigation.

\section{Conclusion}

Guaranteeing safety and security are some of the most important tasks of today's hazards factor prevention and the preparation for response. Looking at the security policy objectives of our country, I have found that due to the complexity of the hazard and the preventive protection activity, we can only look for preventive protection issues effectively when it is in a complex systemic manner. Analysing the components and features of Hungary's protection system systematically, it can be stated that the system has two areas, namely the armed and the civil protection subsystem, which are linked to civil emergency planning. From the implementation side, I have distinguished three subsystems: the task, the organization and the resource subsystems, and I defined their constituents.

I have also defined the features of the protection system based on the security policy documents, summarized in 10 points, demonstrating its complexity. Within the civil protection subsystem, I have examined the place and role of disaster management and its subsystems in the protection system and found that the complex system of protection has a significant correlation with its structure, function and system.

Analysing the control of the hazard factors, I have found that the tasks of the three protection periods (prevention, response/protection, restoration) are of utmost importance nowadays and both the Hungarian and the international security aspirations have focused on the prevention period, because the tasks to be carried out here have a significant impact on the feasibility of the other periods (protection, restoration).

By examining the tasks of the prevention phase with a systems approach, I have found that task groups - to be implemented here-embrace different areas and form an integral unit with each other. International and Hungarian protection objectives and guidelines are the first area that can be implemented by security policy measures.

The tasks that belong to the second area-which are applicable and to be performed during all types of hazards in the prevention phase-through examination and analyses can be classified into 6 categories; such as the appearance of legislation specific protection-targeted requirements, preventive protection investments, spatial (settlement) development, protection planning, training, preparation, and setup of organizations and resources.

The prevention tasks that belong to the third group, apply to a specific protection/defense area. I have investigated the prevention tasks of disaster management (a specific area of the complex system of protection) and determined the task groups to be performed there. They show a significant match with the second task group. They are also classified into six categories and are interrelated and form an integral unit.

From the prevention tasks (belonging to the third group) I have presented the technical nature of two specific examples: with regard to natural fires and floods. I have found that in these two types of disasters today - in addition to the traditional forms of prevention-new technologies and developments have become increasingly important, based on the research 
J. HORNYACSEK: The Relationship Between the Tasks Aimed at the Prevention of Extraordinary...

results of recent years and the application of new principles and methods of protection. I gave examples from Hungarian and international practice.

The analysis did not address protection-related tasks of the protection factors and their correlations with the components of the protection system, thus they require further research.

\section{References}

[1] United Nations: Sendai Framework for Disaster Risk Reduction 2015-2030.

[2] 2073/2004. (IV. 15.) Government Decree on the National Security Strategy of the Republic of Hungary.

[3] 1035/2012. (II. 21.) Government Decree on the National Security Strategy of Hungary.

[4] HORNYACSEK J.: A biztonságunkat veszélyeztető tényezők és a katasztrófák elleni védekezés átfogó megközelítése. Hadmérnök, 1 (2017), 84-114.

[5] BUCZKÓ G.: Kelet-Közép-Európa biztonságpolitikája a NATO 1990-es bővítését követően. Budapest: Budapesti Gazdasági Főiskola, 2004.

[6] Act CXIII of 2011 on home defence and the Hungarian Defence Forces, and the measures that can be taken in special legal order.

[7] 90/2011. (XII. 22.) Government Decree on home defence and the Hungarian Defence Forces.

[8] The Fundamental Law of Hungary (25 April 2011).

[9] Act CXXVIII of 2011 (03. 10. 2011) on the amendment of the Act on Disaster Management and certain relevant acts.

[10] 234/2011. (XI. 10.) Government Decree on the implementation of Act CXXVIII of 2011 on the amendment of the Act on Disaster Management and certain relevant acts.

[11] 62/2011. (XII. 29.) MoI Decree on certain rules of the protection against disasters.

[12] Act CXIII of 2011 on home defence and the Hungarian Defence Forces, and the measures that can be taken in special legal order.

[13] 23/2005. (VI. 16.) MoD Decree on the direction and tasks of the protection against disasters by the defence sector.

[14] BONNYAI T.: A katasztrófavédelem integrált rendszere. Budapest: NKE, 2013.

[15] HORNYACSEK J.: A települési védelmi képességek a katasztrófa-kihívások tükrében. Budapest: Biztonságunk Érdekében Egyesület, 2011.

[16] Sierra Forest Legacy: Ecological Burning in the Sierra Nevada. www.sierraforestlegacy.org/ Resources/Conservation/FireForestEcology/FireScienceResearch/FuelsManagement/FMSFLFireWhitePaper2011.pdf (Downloaded: 0502 2017).

[17] Forest Fire Research Questions the Wisdom of Prescribed Burns. New York Times, 18. 09. 2012. www.nytimes.com/2012/09/18/science/earth/forest-survey-questions-effect-ofprescribed-burns.html, https://ec.europa.eu/jrc/en/research-topic/fires (Downloaded: 0502 2017),

[18] KARDOS I.: Az erdőgazdálkodók tûzmegelőzési és tüzoltási feladatai és lehetőségei. www. katasztrofavedelem.hu/letoltes/konferencia/4/2_sefag_Kardos.pdf (Downloaded: 0502 2017).

[19] BRADLEY, M. M., SCHEMER, C. L., SUMIKAWA, D. A., WALKER, H., YOUNKER, L. W., BOSSERT, J. E., HANSON, H. P., LINN, R. R., REISNE, J. M.: The National Wildfire 
J. HORNYACSEK: The Relationship Between the Tasks Aimed at the Prevention of Extraordinary...

Prediction Program: A Key Piece of the Wildfire Solution. Los Alamos: Lawrence Livermore National Laboratory, 1999. https://e-reports-ext.llnl.gov/pdf/236394.pdf (Downloaded 2411 2005).

[20] HELLER, A.: This Model Can Take the Heat: A New Computer Program Simulates the Physics of Fire and Weather Patterns to Help Combat Wildfires. 2002. www.llnl.gov/str. November02/Bradley.html (Downloaded: 2311 2005).

[21] PATZELT, S.: Deutschland: Zukunftsorientierte Strategien und Konzepte unter besonderer Berücksichtigung der Brandbekämpfung aus der Luft. Dissertation. Mainz: Johannes Guttenberg Univesität, 2008.

[22] Phos-check. www.phos-chek.com.au/retardant (Downloaded: 1702 2017).

[23] Drónok használata a hétköznapokban. Lendület Portál, 12. 08. 2014. www.lendulet.hu/ dronok-hasznalata-hetkoznapokban/ (Downloaded: 0501 2017).

[24] TÓTH R.: A repülőeszközök alkalmazásának lehetséges területei és korlátai katasztrófák esetén. Repüléstudományi Közlemények, 232 (2011), 1-26.

[25] GOLDAMMER, J. G.: Zur Entwicklung von Systemen der Waldbrandbekämpfung aus der Luft: In Kampf dem Waldbrand. Sonderheft der Allgemeinen Forst Zeitschrift, 28 (1978), 42-43.

[26] Chemical Alternatives Assessment of Different Flame-Retardants: A Case Study Including Multiwalled Carbon Nanotubes as Synergist. https://ec.europa.eu/jrc/en/publication/ chemical-alternatives-assessment-different-flame-retardants-case-study-including-multiwalled-carbon (Downloaded: 1512 2016).

[27] Leben mit dem Wasser. Hochwasserschutz in Holland. www.handelsblatt.com/technik/ energie-umwelt/hochwasserschutz-in-holland-leben-mit-dem-wasser/8352266.html (Downloaded: 1512 2016).

[28] LEHNEN-BEYEL, I.: Gefahr durch Überschwemmungen wächst. www.wissenschaft.de/ home/-/journal_content/56/12054/1118000/ (Downloaded:18 12 2016).

[29] Flooding. Ucar.edu, www.ucar.edu/communications/factsheets/Flooding.html (Downloaded: 2012 2016).

[30] NAGY I.: A Tisza-völgy árvízi helyzetének bemutatása, árvízi kockázatok, aktualitások. Szolnok: Jász-Nagykun-Szolnok Megyei Mérnöki Kamara, 2012. http://docplayer. hu/1127391-A-tisza-volgy-arvizi-helyzetenek-bemutatasa-arvizi-kockazatok-aktualitasokdr-nagy-istvan.html (Downloaded:15 12 2016).

[31] MÉHÉSZ N.: Árvízi kockázat-kezelés egyes módszertani kérdései. Nyíregyháza: Víziterv Environ Kft. http://docplayer.hu/34766224-Az-arvizi-kockazatkezeles-akk-egyesmodszertani-kerdesei-mehesz-nora-viziterv-environ-kft.html (Downloaded: 1512 2016).

[32] BEREK T.: A vízbiztonsági tervezés szerepe a fenntartható vízgazdálkodásban. Müszaki Katonai Közlöny, 262 (2016), 32-48.

[33] Hungarian Investment and Trade Agency: The Hungarian Water and Sanitation Industry in the $21^{\text {st }}$ century. 2013. www.budapestwatersummit.hu/data/images/BWS_news_water_ and_sanitation_hu_brossure.pdf (Downloaded: 2312 2016).

[34] BÁRDOS Z.: Az önkormányzati ár- és belvizek elleni védekezés feladatai korszerüsítésének lehetőségei. PhD-értekezés. Budapest: Nemzeti Közszolgálati Egyetem, 2016.

[35] Drénezés. http://szolo.blog.hu/2015/05/16/alagcsovezes_drenezes (Downloaded: 1512 2016).

[36] Pro Aqua Kft.: Az árvízvédekezés feladatai. Budapest, s.d. http://proaquakft.lapunk. hu/?modul=oldal\&tartalom=1190518 (Downloaded: 1512 2016). 
J. HORNYACSEK: The Relationship Between the Tasks Aimed at the Prevention of Extraordinary...

[37] DÉNES M.: Mobilgátak: Igen vagy nem? Magyar Építéstechnika, 2015. 07. 15. www. magyarepitestechnika.hu/index.php/2015-6/2678-mobilgatak-igen-vagy-nem\#\&panel2-1 (Downloaded: 1512 2016).

[38] IBS: Mobile flood protection walls. http://mobilgat.hu/mobilewalls.php (Downloaded: 1512 2016).

[39] Quickdamm. www.domobau.hu/mobilgat.html (Downloaded: 1512 2016).

[40] Bewährungsprobe für die rote Tonne. FAZ.net,14 012011 www.faz.net/aktuell/rhein-main/ frankfurt/hochwasserschutz-bewaehrungsprobe-fuer-die-rote-tonne-1578261/aquariwagegen-quickdamm-beim-1587670.html\#fotobox_1_578261 (Downloaded: 1512 2016).

[41] Ipoly árvízi elörejelzés: Közös, integrált, valós idejü hidrológiai elörejelző rendszer kialakítása az Ipoly vízgyűjtőjére. Budapest: Közép-Duna-völgyi Vízügyi Igazgatóság, s.d. www.kdvvizig.hu/index.php/projektek/nemzetkozi-palyazatok/149-ipoly-arvizielorejelzes/315-ipoly-arvizi-elorejelzes (Downloaded: 1512 2016).

[42] PADÁNYI J., FÖLDI L.: Tasks and Experiences of the Hungarian Defence Forces in Crisis Management. Bilten Slovenske Vojske, 171 (2015), 29-46.

[43] PADÁNYI J.: Experience in the Use of Military Forces in Flood Protection. AARMS, 121 (2013), 59-66.

[44] BÁRDOS Z., MUHORAY Á.: A települések vízkár elleni védekezési feladatainak változása a megváltozott jogszabályi környezetben. Hadmérnök, 93 (2014), 48-60. 